\title{
Pseudomonas fluorescens Isolates Used as a Plant Growth Promoter of Faba Bean (Vicia faba) in Vitro as Well as in Vivo Study in Ethiopia
}

\author{
Fekadu Alemu' ${ }^{1}$, Tesfaye Alemu ${ }^{2}$ \\ ${ }^{1}$ Department of Biology, College of Natural and Computational Sciences, Dilla University, Dilla, Ethiopia \\ ${ }^{2}$ Department of Microbial, Cellular and Molecular Biology, College of Natural Sciences, Addis Ababa University, Addis Ababa, Ethiopia
}

Email address:

fekealex@gmail.com (F. Alemu)

\section{To cite this article:}

Fekadu Alemu, Tesfaye Alemu. Pseudomonas fluorescens Isolates Used as a Plant Growth Promoter of Faba Bean (Vicia faba) in Vitro as Well as in Vivo Study in Ethiopia. American Journal of Life Sciences. Vol. 3, No. 2, 2015, pp. 100-108. doi: 10.11648/j.ajls.20150302.17

\begin{abstract}
Production of the crop is affected by deficiency of fertilizers and low number of plant growth promoting rhizobacteria in soil. At the present study, Pseudomonas fluorescens isolates possess a variety of promising properties which make it a good plant growth promoting traits. Twelve $P$. fluorescens isolates from rhizospheric soil of faba bean were isolated and assessed in vitro for their plant growth promoting activity based on their ability to produce hydrogen cyanide (HCN), siderophores, indole acetic acid (IAA), and ammonia and phosphate solubilization. The results indicated that most of the isolates tested possess plant growth promoting traits. Bio-primed faba bean seed with $P$. fluorescens 9 and $P$. fluorescens 10 for plant growth promoting activities in green house showed a positive result. In addition, these to two isolates increased faba bean leaves number, branches number, height, root length, lateral roots and number of nodule per plant. Therefore, from this study it is possible to conclude that the use of P. fluorescens 9 and 10 isolates could increase the faba bean growth and yield performance. These isolates can be used as potential biofertilizers and plant growth promoter.
\end{abstract}

Keywords: Faba Bean, Growth Promote, Phosphate Solubilization, P. fluorescens, Siderophore

\section{Introduction}

The diversity and beneficial activity of the plant-bacterial association and its understanding is important to sustain agroecosystems for sustainable crop production (Germida et al., 1998). The rhizosphere is representing the thin layer of soil surrounding plant roots. The rhizosphere, supports large active groups of bacteria (Villacieros et al., 2003) known as plant growth promoting rhizobacteria (PGPR) (Kloepper et al., 1980). Plant growth promoting rhizobacteria are known to rapidly colonize the rhizosphere, suppress soil borne pathogens at the root surface (Rangajaran et al., 2003) and to stimulate plant growth (Bloemberg and Lugtenberg, 2001; Moeinzadeh et al., 2010). Some Pseudomonas sp P., especially fluorescent pseudomonads, are particularly suitable to be used as agricultural biocontrol agents because they can produce large amounts of secondary metabolites to protect plants from phytopathogens and stimulate plant growth.

Plant growth promoting rhizobacteria (PGPR) were defined as the soil bacteria that colonize the roots of plants by following inoculation on to seed and that enhance plant growth (Kloepper and Schroth, 1978). The plant growthpromoting ability of these bacteria is generated mainly by the production of indole-3-acetic acid (IAA), siderophores and some well-known antibiotics (Nagarajkumar et al., 2004), hydrogen cyanide (HCN) (Voisard et al., 1989), phosphate solubilize (Rodríguez and Fraga, 1999).

Pseudomonas fluorescens is adapted to survival in soil and colonization of plant roots (Kiely et al., 2006) and this applies also to the particular case of biocontrol agents from this species. The microbial inoculants that are used in agriculture include biofertilizers, biocontrol agents and plant growth promoting rhizobacteria. While the biofertilizer organisms make the nutrients available to plants, biocontrol agents protect the plants against the pathogenic organisms and insect pests. Bio-priming, a seed treatment system that integrates the biological and physiological aspects of disease control, involves coating the seed with fungal or bacterial biocontrol agents (El-Mougy and Abdel-Kader, 2008). Bioprotectants applied to seeds, protect seeds (Sivan and Chet, 1986) colonise and protect roots (Chang et al., 1986) 
and may increase plant growth. A successful antagonist should colonise the rhizosphere during seed germination (Weller, 1983).

Indole-3-acetic acid (IAA) is implicated in signaling between microorganism and plants (Spaepen et al., 2007) leading to stimulation of cell division, initiation of lateral and adventitious roots (Malamy and Benfry, 1997), cell enlargement (Salisbury, 1994) and results into elongation of stems and roots. The stimulation of growth of roots results in enhances uptakes of nutrients plants association (Lifshitz et al., 1987). Biofertilizers such as microbial inoculants promote plant growth, productivity and increase the nutrient status of the host plant. This produce has internationally been accepted as an alternative source of chemical fertilizers (Vessey, 2003).

Siderophores act as solubilizing agents for iron from minerals or organic compounds under conditions of iron limitation (Indiragandhi et al., 2008). Antibiotics are chemically heterogeneous group of organic, low molecular weight compounds produced by microorganisms (Raaijmakers et al., 2002). This is first study of $P$. fluorescens role on faba bean crop to increase the growth and yield. As result these isolates have great contribution on growth promoting of faba bean in agriculture production. The present study was firstly designed to isolate certain rhizospheric of Pseudomonas fluorescens from faba bean root soil for assessment of their production of plant growth promoting substances (PGPS) in vitro study. Secondly to evaluate plant growth promoting substances effect on faba bean crop growth as well as yield in green house test through biopriming method on faba bean seed.

\section{Materials and Methods}

\subsection{Soil Sample Collection and bacteria Isolation}

Rhizospheric soil samples were collected in an envelope from fields growing faba bean (Vicia faba L.) from five locality area of North Showa of Oromeia Regional state of Salele Zone, Ethiopia. The soils were brought to Mycology Laboratory, Addis Ababa University. Ten gram (10 g) of rhizosphere soil sample was suspended in $90 \mathrm{ml}$ of sterile distilled water. Samples were serially diluted up to $10^{-2}$ and $0.1 \mathrm{ml}$ of sample was spreaded on King's B medium plates (King et al., 1954) incubated at $28^{\circ} \mathrm{C}$ for $48 \mathrm{~h}$. After incubation the plates were exposed to UV light at $365 \mathrm{~nm}$ for few seconds and the colonies exhibiting the fluorescence were picked up and purified on King's B medium plates. Twelve strains of $P$. fluorescens were isolated and they were designated as Pf 1 up to Pf 12 for further studies.

\subsection{Source of Faba Bean Seed and Chocolate Spot Pathogen}

One isolate of Botrytis fabae was obtained from Holeta Agricultural Research Centre, Ethiopia which was isolated from the leaf of infected faba bean which was grown around Holeta locality. The seeds of faba bean varieties used in the present work were obtained from Holeta Agriculture Research Centre, Ethiopia. The three varieties of faba bean seed (namely: NC 58 susceptible variety, Moti moderate variety and ILB 938 restively resistant variety) was obtained from Holeta Agriculture Research Center (figure 1).

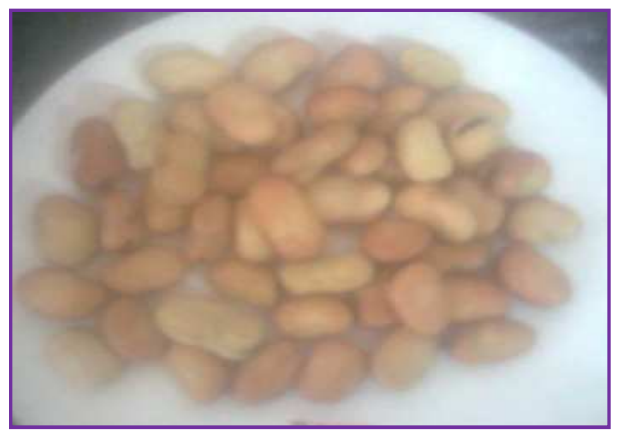

Figure 1. Faba bean sample.

\subsection{Biochemical Characterization of P. fluorescens Isolates for Plant Growth Promoting (PGP) Traits}

\subsubsection{Assay for Siderophore Production}

Siderophore production was tested by growing $P$. fluorescens isolates on the king's B medium at $28^{\circ} \mathrm{c}$ for 48 hours. The plates were exposed to UV light for 30 seconds and the isolate with pigment were exhibiting the fluorescence (Ramyasmruthi et al., 2012).

\subsubsection{Assay for Hydrogen Cyanide Production}

Hydrogen cyanide production was assayed by the method suggested by (Castric, 1977; Lorck, 1948). For the production of $\mathrm{HCN}$, P. fluorescens isolates were streaked into King's B agar plates supplemented with glycine $(4.4 \mathrm{~g} / \mathrm{l})$. After wards, plates were inverted and a piece of filter paper impregnated with $0.5 \%$ picric acid and $2 \%$ of sodium carbonate was placed on the lid. Petri plates were sealed with parafilm and incubated at $28^{\circ} \mathrm{C}$ for $96 \mathrm{~h}$. Production of cyanide was determined by a color shift from yellow to orange in the filter paper (Castric, 1975).

\subsubsection{Assay for Indole Acetic Acid (IAA) Production}

All the Pseudomonas fluorescens isolates were tested for IAA production (Loper and Schroth, 1986). P. fluorescens isolates were inoculated in nutrient broth with L-tryptophan $500 \mathrm{mg} / \mathrm{l}$ at $28{ }^{0} \mathrm{C}$ for 1 week. Fully grown cultures were centrifuged at $3000 \mathrm{rpm}$ for $30 \mathrm{~min}$, then $2 \mathrm{ml}$ of supernatant was mixed with two drops of orthophosphoric acid and $4 \mathrm{ml}$ of the Salkowski reagent $(50 \mathrm{ml}, 35 \%$ of perchloric acid, 1 $\mathrm{ml} 0.5 \mathrm{M} \mathrm{FeCl3}$ solution). Development of pink color indicates IAA production was determined (Bric et al., 1991).

\subsubsection{Assay for Ammonia Production}

P. fluorescens isolates were tested for the production of ammonia in peptone water. Freshly grown cultures were inoculated in $10 \mathrm{ml}$ peptone water and incubated for $72 \mathrm{~h}$ at $28^{\circ} \mathrm{C}$. Then Nessler's reagent $(0.5 \mathrm{ml})$ was added in each tube. Development of brown to yellow colour was a positive for ammonia production (Cappuccino and Sherman, 2005). 


\subsubsection{Assay for Phosphate-Solubilization}

Phosphate-solubilization test was conducted qualitatively by plating the $P$. fluorescens isolates in agar containing precipitated tricalcium phosphate. The medium was a modification of Pikovskaya medium (Subba Rao, 1999), consisted of $10 \mathrm{~g}$ glucose, $5 \mathrm{~g}$ tribasic phosphate $\left(\mathrm{Ca}_{3}\left(\mathrm{PO}_{4}\right)_{2}\right)$,

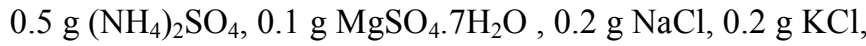
$0.002 \mathrm{~g}$ trace of $\mathrm{MnSO}_{4} \cdot \mathrm{H}_{2} \mathrm{O}$ and $\mathrm{FeSO}_{4} .7 \mathrm{H}_{2} \mathrm{O}, 0.5 \mathrm{~g}$ yeast extract, and $20 \mathrm{~g}$ agar, in $1,000 \mathrm{ml}$ distilled water. Pseudomonas fluorescens isolates culture were streaked on the surface of agar plates and incubated at $28^{\circ} \mathrm{C}$ for 3 days. After 3 days of incubation, the colonies showing the clear zones around them were considered as positive for positive P-solubilization.

\subsection{Preparation of Bacteria Inoculum and Bio-Priming of Faba Bean Seeds}

Carboxymethyl cellulose (CMC) and pectin were used as adhesive polymers for the bio-priming process of three varieties of faba bean seeds with antagonistic bioagent. $P$. fluorescens isolates was grown for $48 \mathrm{~h}$ in King's B (KB) broth medium, and then cells were harvested by centrifugation. Two isolates of $P$. fluorescens (Pf 9 and $\mathrm{Pf} 10)$ were resuspended in sterile distilled water and the concentration adjusted to give $10^{9}-10^{10}$ cells $/ \mathrm{ml}$ (El-Mougy and Abdel-Kader, 2008). Ten grams of either CMC or pectin was suspended in $1 \mathrm{~L}$ of $P$. fluorescens isolates suspensions, which were shaken for $10 \mathrm{~min}$ on a magnetic stirrer plate. Seeds of faba bean (at the ratio of $500 \mathrm{~g} / \mathrm{L}$ ) were imbibed in each of the prepared priming solutions for $16 \mathrm{~h}$ (Jensen et al., 2004).

The bio-primed seeds were then air-dried on filter paper for $1 \mathrm{~h}$ and stored in a refrigerator at $5^{\circ} \mathrm{C}$ until required. Another group of surface-sterilized faba bean seeds $(70 \%$ ethanol for $2 \mathrm{~min}$ ) were prepared as control treatments (ElMougy and Abdel-Kader, 2008).

\subsection{Growth and Yield Parameters Data Collection}

Growth parameters (plant height $(\mathrm{cm})$, number of leaves, branches, nodule number (Alemayehu, 2009) root length $(\mathrm{cm})$ per plant) were collected at 70 days (El-Ghamry et al., 2009) and after 5 months yield parameters (shoot fresh weight $(\mathrm{g})$, number of pods per plant, weight of pods/plant $(\mathrm{g})$ and number of seeds/ plant) were collected.

\section{Data Analysis}

All the measurements were replicated three times for each assay and the results are presented as mean \pm SD. IBM SPSS 20 Version statistical software package was used for statistical analysis of growth and yield parameter in each case.

\section{Results}

Isolation of Pseudomonas fluorescens

At the present study, twelve P. fluorescens were isolated from rhizospheric soil of healthy faba bean on King's B medium and observed under UV light at $365 \mathrm{~nm}$ for 30 seconds as indicated figure 2 .

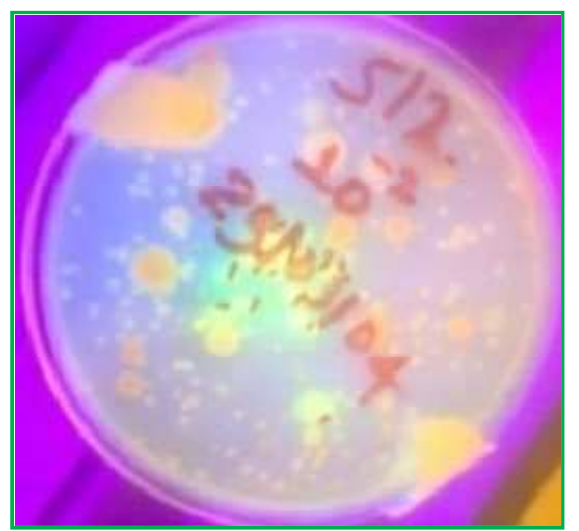

Figure 2. Primarily screening of Pseudomonas fluorescens based on pigment production under UV light

\subsection{In Vitro Production of Plant Growth Promoting Substances}

All of $P$. fluorescens isolates were positive for produced plant growth promoting substances. All the strains were positive for siderophore, hydrogen cyanide ( $\mathrm{HCN})$, indole acetic acid (IAA) and ammonia production and also for phosphate-solubilization as indicted figure 3 .

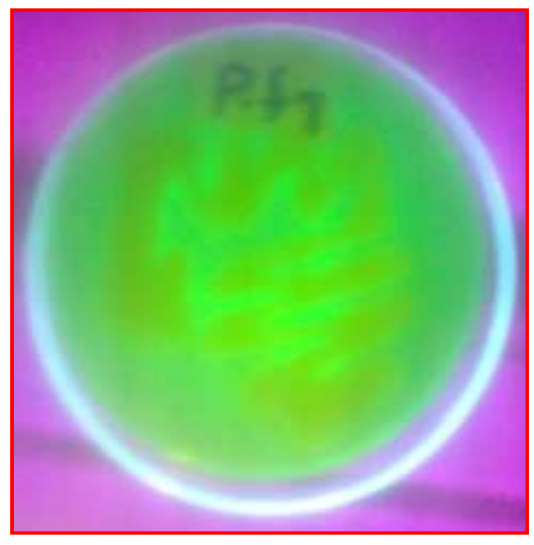

A

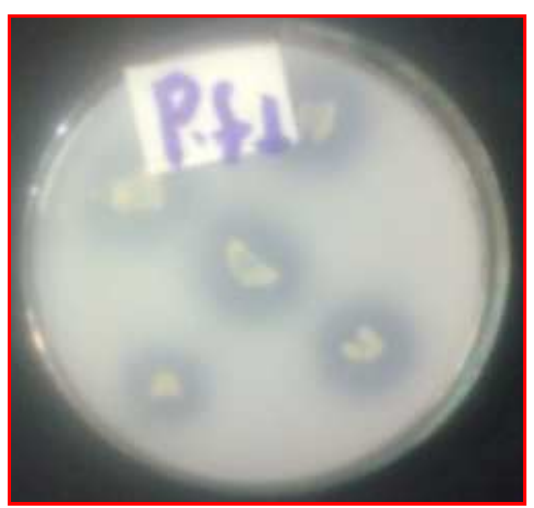

B 


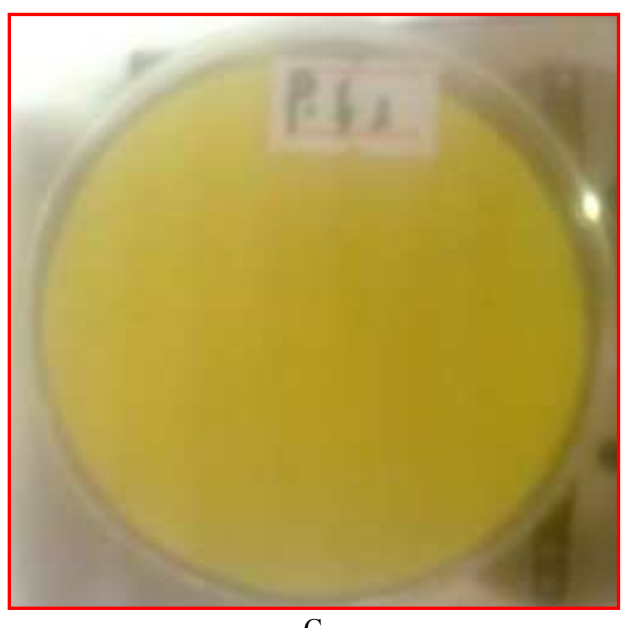

$\mathrm{C}$
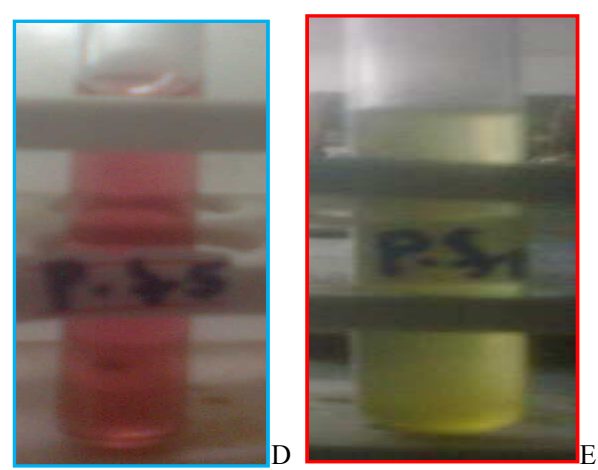

Figure 3. Production of plant (crop) promoting traits by Pseudomonas fluorescens isolates: A, Siderophore production; B, Phosphate-Solubilization; $C$, Hydrogen cyanide (HCN) production; D, Indole acetic acid (IAA) production and E, Ammonia production.

\subsection{Plant Growth Parameters}

\subsubsection{Effect of Pseudomonas fluorescens Isolates (Pf 9 and Pf 10) on Growth Parameters under Greenhouse Conditions}

The use of bio-priming seeds of faba bean of NC 58, Moti and ILB 938 varieties with Pf 9 and Pf 10 treatments were showed significantly increase number of leaves/plant over untreated (negative control or infected untreated plant) and positive control (Uninfected untreated plants) as indicated in Table 1 after 70 days of planting of faba bean.

Two isolates of P. fluorescens (Pf 9 and Pf 10) enhanced the number of branches/plant significantly over negative and positive control. Bio-primed seed of faba bean with Pf 9 increased the number of branches per plants on NC 58, Moti and ILB 938 varieties, while bio-primed seed of faba bean with Pf 10 increased the number of branches per plants on NC 58, Moti and ILB 938 varieties as indicated in Table 1 after 70 days of planting of faba bean.

The result in Table 1 indicated bio-primed seed of faba bean with Pf 9 increased height of plants on of Moti, NC 58 and ILB 938 varieties and with Pf 10 increased the height of plants on NC 58, ILB 938 and Moti varieties as, compared negative and positive control after 70 days of planting of faba bean.

The result showed that bio-primed faba bean seeds with Pf 9 and $\mathrm{Pf} 10$ showed an increase in the nodule number average per plant of the varieties in Table 2 .

Bio-primed faba bean seeds with Pf 9 and Pf 10 showed increase of the root length per plant of NC 58, ILB 938 and Moti after 70 day as showed in Table 2.

Table 1. Effect of two Psedomonas fluorescens isolates (Pf 9 and Pf 10) on growth parameter of faba bean plants.

\begin{tabular}{llll}
\hline & \multicolumn{2}{l}{ After 70 days } & \\
\cline { 2 - 4 } Treatments and controls & $\begin{array}{l}\mathbf{N}^{\mathbf{0}} \text { leaves per plant } \\
\text { Mean } \pm \text { SD }\end{array}$ & $\begin{array}{l}\mathbf{N}^{\mathbf{o}} \text { branches per plant } \\
\text { Mean } \pm \text { SD }\end{array}$ & $\begin{array}{l}\text { Plant height(cm) } \\
\text { Mean } \pm \text { SD }\end{array}$ \\
\hline Pf 9 NC 58 & $65.33 \pm 8.927$ & $1.75 \pm 1.055$ & $87.25 \pm 3.720$ \\
Pf 9 Moti & $75.25 \pm 21.239$ & $2.25 \pm 0.965$ & $86.92 \pm 9.624$ \\
Pf 9 ILB 938 & $67.83 \pm 13.114$ & $1.67 \pm 0.651$ & $88.25 \pm 6.254$ \\
Pf 10 NC 58 & $70.58 \pm 9.811$ & $2.42 \pm 0.793$ & $84.67 \pm 2.807$ \\
Pf 10 Moti & $83.08 \pm 11.261$ & $2.58 \pm 0.996$ & $91.92 \pm 7.573$ \\
Pf 10 ILB 938 & $79.50 \pm 34.259$ & $1.17 \pm 0.937$ & $90.08 \pm 16.149$ \\
Negative Control NC58 & $61.67 \pm 7.608$ & $1.58 \pm 0.515$ & $84.42 \pm 6.626$ \\
Negative Control Moti & $66.33 \pm 11.372$ & $2.00 \pm 0.603$ & $82.17 \pm 8.840$ \\
Negative Control ILB 938 & $60.42 \pm 13.787$ & $1.42 \pm 1.165$ & $83.75 \pm 8.081$ \\
Positive Control NC 58 & $62.00 \pm 8.224$ & $1.83 \pm 0.835$ & $84.25 \pm 6.982$ \\
Positive Control Moti & $72.08 \pm 10.131$ & $2.08 \pm 1.165$ \\
Positive Control ILB 938 & $61.50 \pm 8.459$ & $81.00 \pm 4.767$ \\
\hline
\end{tabular}

Key: Mean, $\mathrm{SD}=$ Standard deviation, NC 58, Moti and ILB 938 are faba bean varieties

Table 2. The effect Pseudomonas fluorescens isolates (Pf 9 and Pf 10) on nodulation and Root length of faba bean.

\begin{tabular}{lll}
\hline & After 70 days & Root length (cm) root system \\
\cline { 2 - 3 } Treatments and controls & $\begin{array}{l}\text { Nodule number/plant } \\
\text { Mean } \pm \text { SD }\end{array}$ & Mean \pm SD \\
\hline Pf 9 NC 58 & $33.25 \pm 3.304$ & $32.50 \pm 2.082$ \\
Pf 9 Moti & $61.50 \pm 1.915$ & $49.75 \pm 15.966$ \\
Pf 9ILB 938 & $50.00 \pm 17.049$ & $44.75 \pm 5.500$ \\
Pf 10 NC 58 & $35.00 \pm 10.893$ & $34.75 \pm 13.598$ \\
Pf 10 Moti & $68.25 \pm 9.215$ & $53.00 \pm 11.518$ \\
Pf 10 ILB 938 & $81.25 \pm 12.066$ & $45.00 \pm 3.916$ \\
\hline
\end{tabular}




\begin{tabular}{lll}
\hline \multirow{2}{*}{ Treatments and controls } & After 70 days & \\
\cline { 2 - 3 } & $\begin{array}{l}\text { Nodule number/plant } \\
\text { Mean } \pm \text { SD }\end{array}$ & $\begin{array}{l}\text { Root length (cm) root system } \\
\text { Mean } \pm \text { SD }\end{array}$ \\
\hline NC 58 Negative control & $28.50 \pm 13.669$ & $21.00 \pm 7.257$ \\
Moti Negative Control & $48.25 \pm 8.884$ & $22.75 \pm 13.048$ \\
ILB 938 Negative control & $33.50 \pm 10.661$ & $30.25 \pm 7.762$ \\
NC 58 Positive control & $29.00 \pm 11.576$ & $24.25 \pm 3.775$ \\
Moti Positive control & $56.00 \pm 18.312$ & $35.13 \pm 18.993$ \\
ILB 938 Positive Control & $40.75 \pm 15.649$ & $35.25 \pm 12.553$ \\
\hline
\end{tabular}

Key: Negative control= seed of faba bean (NC 58, Moti and ILB 938) with Botrytis fabae without using P. fluorescens as Bio-priming sowing

Positive control= only sowing faba bean seed (NC 58, Moti and ILB 938) without of inoculating both bio-control (P. fluorescens) and pathogen (Botrytis fabae)

\subsubsection{Effect of Pseudomonas fluorescens Isolates (P $f^{9}$ and $P$ f10) on Yield Parameters under Greenhouse Conditions}

The use of bio-priming seeds of faba bean (NC 58, Moti and ILB 938 varieties) with Pf 9 and Pf 10 showed increase in shoot fresh weight of faba bean over untreated (negative control or infected untreated plant) and positive control (Uninfected untreated plants) as indicated in Table 3.

The two isolates of $P$. fluorescens enhanced the number of pods per plant significantly over negative and positive control. Bio-primed seed of faba bean with Pf 9 increased the number of branches per plants on NC 58, Moti and ILB 938 varieties, while bio-primed seed of faba bean with Pf 10 increased the number of pods per plants on NC 58, Moti and ILB 938 varieties as indicated in Table 3.

As result indicated bio-primed seed of faba bean with Pf 9 increased height of plants on of NC 58, Moti and ILB 938 varieties and with $\mathrm{Pf} 10$ increased the weight of pods/plant on NC 58, Moti and ILB 938 varieties as, compared negative and positive control in Table 3 .

The result showed that bio-primed of faba bean seeds with Pf 9 were increased the number of seeds/plant of NC 58, Moti and ILB 938, while bio-primed with Pf 10 also increased the number of seeds/ plant of NC 58, Moti and ILB 938 as indicated in Table 3 after 5 months.

Table 3. Effect of P. fluorescens 9 and 10 strains treatments on yield parameters of faba bean plants under greenhouse condition after 5 months.

\begin{tabular}{lllll}
\hline \multirow{2}{*}{ Treatments and Controls } & Yield Parameters & & & Weight \\
\cline { 2 - 5 } & $\begin{array}{l}\text { Shoot fresh } \\
\text { weight (g) }\end{array}$ & $\begin{array}{l}\text { Number } \\
\text { pods/plant }\end{array}$ & $\begin{array}{l}\text { Number of } \\
\text { seeds/ plant }\end{array}$ \\
\hline Pf 9 NC 58 & 83.20 & 4.13 & 4.50 & 6.35 \\
Pf 9 Moti & 232.10 & 5.50 & 8.50 & 10.25 \\
Pf 9 ILB 938 & 360.30 & 6.34 & 9.24 & 17.32 \\
Pf10 NC 58 & 235.12 & 5.37 & 5.63 & 7.75 \\
Pf 10 Moti & 225.90 & 5.16 & 7.12 & 9.89 \\
Pf 10 ILB 938 & 517.70 & 9.89 & 17.40 & 44.12 \\
Negative Control NC58 & 131.30 & 1.20 & 1.50 & 2.10 \\
Negative Control Moti & 200.40 & 1.89 & 1.90 & 2.13 \\
Negative Control ILB 938 & 257.09 & 0.00 & 0.00 & 0.00 \\
Positive Control NC 58 & 165.47 & 3.57 & 3.96 & 4.81 \\
Positive Control Moti & 215.01 & 4.12 & 4.53 & 5.21 \\
Positive Control ILB 938 & 350.00 & 8.76 & 12.17 & 18.28 \\
\hline
\end{tabular}

\section{Discussion}

\subsection{In Vitro Production of Plant Growth Promoting Substances (PGPS)}

In present study, $P$. fluorescens isolates showed PGP traits like phosphate-solubilization, siderophore production, hydrogen cyanide production, ammonia production, and indole acetic acid (IAA) production. Hence, these isolates have been used as biocontrol agents and plant growth promoting rhizobacteria (PGPR). The exact mechanism by which PGPR stimulate plant growth is not clearly known, although several mechanisms such as production of phytohormones, suppression of deleterious organisms, activation of phosphate solubilization and promotion of the mineral nutrient uptake are usually believed to be involved in plant growth promotion (Glick, 1995) and inhibit the growth of plant pathogens by diverse mechanisms such as antibiotic production (Nagarajkumar et al., 2004), siderophore production (Loper, 1988), HCN release (Voisard et al., 1989) and competitive colonization of plant roots (Weller, 1985).

In this study, the qualitative estimation of siderophores by Pseudomonas fluorescens isolates showed that they were compare with producer of siderophores under limited iron on King's B medium. The production of siderophores by Pseudomonas fluorescens isolates indicated that these bacteria isolates can be used as a bio-control against soil borne phytopathogens. Similarly, (Ramyasmruthi et al., 2012) reported that $P$. fluorescens as siderophore producer on King's B medium. Siderophores provide a competitive advantage to producer organism over fungal pathogens for the absorption of available iron (Jeffrey et al., 2003). 
In the present study, all $P$. fluorescens isolates were positive for $\mathrm{HCN}$ production, which acts as an inducer of plant resistance. On other study, $\mathrm{HCN}$ is a secondary metabolite produced by gram negative $P$. fluorescens, $P$. aeruginosa and Chromobacterium violaceum (Askeland and Morrison, 1983) and played a role in biological control of pathogens. This compound, although reported as a potential inhibitor of enzymes involved in major plant metabolic processes (Castric, 1975) is currently attracting remarkable attention and wide applications in areas of biocontrol methods. HCN production by rhizobacteria has been postulated to play an important role in the biological control of pathogens (Lifshitz et al., 1987).

Applications of growth promoter of Pseudomonas fluorescens isolates on faba bean seed were brought significant increases on growth and yield of $\operatorname{cro} P$. The increment in growth parameter may be due to that Pf 9 and Pf 10 are extremely important component because they constitute a stable fraction of carbon, thus regulating the carbon cycle and release of nutrients, including nitrogen and phosphorus which decreasing the need for inorganic fertilizer for plant growth. Similarly, the use of Tichoderma viride tag4 in combined with Rhizobium leguminosarum is an effective strategy for an integrated management of chocolate spot disease as well as increasing growth and productivity of faba bean (Saber et al., 2009).

\subsection{Growth Promotes}

Bio-primed seed of faba bean with Pf 9 and Pf 10 increased the number of leaves per plants on NC 58, Moti and ILB 938 varieties. The highest number of leaves per plants (75.25 leaves/plant) observed on ILB 938 variety. On other study, Trichoderma harzianum significantly increased number of leaves in treated bean plants were 15.2 leaves/plant, while in untreated plants were 9.5 leaves/plant (Abd-El-Khair et al., 2010). Application of humic acids (HA) at $2000+$ amino acids (AA) at 2000 ppm came in the top of other treatments in increasing 46.00 leaves number per plant (El-Ghamry et al., 2009). It has been reported that seed treatment with Bion and Salicylic acid achieved highest faba bean shoot length at 0.36 and 0.34 double field dose (D.F.D.) 26.0 leaves per plants respectively (Mahmoud et al., 2011).

Pf 9 showed the maximum number of branches in Moti and ILB 938 varieties 2.25 branches/plant and bio-primed with Pf 10 was 2.00 branches/plant of ILB 938 varieties. It has reported that, Trichoderma harzianum significantly increased the branches number average 6.3 branch/plant, compared to 3.7 branch /plant in control treatment (Abd-ElKhair et al., 2010). Application of HA at 2000+ AA at 2000 ppm came in the top of other treatments in increasing 4.67 branches number per plant (El-Ghamry et al., 2009).

The highest shoot length $88.25 \mathrm{~cm}$ was recorded on faba bean plants of ILB 938 variety inoculated with Pf 9 and $91.92 \mathrm{~cm}$ was recorded on Moti variety inoculated with Pf 10 . On other study, Trichoderma hamatum gave the highest increase of plant height $49.8 \mathrm{~cm}$ compared to $37.3 \mathrm{~cm}$ in the control plants (Abd-El-Khair et al., 2010). Application of AA at $3000 \mathrm{ppm}$ increased plant height to $74.33 \mathrm{~cm}$ (Loper, 1988). As Mahmud reported that seed treatment with Bion achieved highest faba bean shoot length at 0.36 D.F.D $54.3 \mathrm{~cm}$ (Mahmud et al., 2011).

The highest numbers of nodule per plant 81.25 and 61.50 nodule/plant were recorded in faba bean ILB 938 and Moti bio-primed with Pf 10 and Pf 9 respectively. It has been reported that highest average nodule number was observed 96 nodules/ plant (Alemayehu, 2009) in faba bean.

The highest root length per plant 49.75 and $53.00 \mathrm{~cm}$ root length/faba bean were recorded in faba bean Moti bio-primed with Pf 9 and Pf 10 respectively. It has been reported that Pseudomonas species produced significant levels of IAA and caused shoot and root elongation in soybean (Xie et al., 1996).

\subsection{Yield Parameters}

Bio-primed seed of faba bean with Pf 9 and Pf 10 increased the shoot fresh weight on 3 varieties. The highest shoot fresh weight (360.30 g) was observed on ILB 938 variety, the while bio-primed seed of faba bean with Pf 10 increased the shoot fresh weight on Moti, NC 58 and ILB 938 varieties and gave maximum shoot fresh weight $(517.70$ g) on ILB 938 variety. The study conducted by (Mahmoud et al., 2011) reported that shoot treatment with bion was the most effective for shoot fresh weight parameters at field dose $(0.18)$ and double filed dose $(0.36)$ dose. It has reported that application of Trichoderma spp. increased the pods number average per plant from 4.2 fresh weight/plant with the control plant to 43.1-77.4 fresh weight/plant in treated plant (Abd-ElKhair et al., 2010).

Treatement Pf 9 showed the maximum number of pods per plant of ILB 938 variety 6.34 numbers of pods /plant and bioprimed with Pf 10 were 9.89 numbers of pods /plant of ILB 938 variety. It has reported that in the case of shoot treatment, salysilic acid was the most effective for number pods/ plant parameters at both field dose (0.32) and double filed dose (0.34), 2.0 and 2.5 (Mahmoud et al., 2011), while in the case of seed treatment with bion at both filed dose (0.18) and double filed dose (0.36) with 2.5 and $4.0 \mathrm{pod} / \mathrm{plant}$ respectively. The study conducted by (Abd-El-Khair et al., 20210) has reported that application of Trichoderma spp. significantly increased the pods number average per plant to 15.2-20.0 pods/plant, compared with10.8 pods/plant in the control plants. It has reported that spraying faba bean plants with humic acid (HA) (2000 ppm) + amino acid (AA) (2000 $\mathrm{ppm}$ ) significantly improved number of pods/ plant at highest level at 67.33 (El-Ghamry et al., 2009). It has reported that chemical inducer of $\mathrm{KH}_{2} \mathrm{PO}_{4}$ with seed treated increase the number of pods/plant 24.7, as compared with control 16.5 (El-Hendawy et al., 2010).

The highest weight of pods/plant 17.40 and $9.24 \mathrm{~g}$ were recorded in faba bean ILB 938 bio-primed with Pf 10 and Pf 9 respectively. The study conducted has reported that application of Trichoderma spp. significantly increased the pods number average per plant where the number were in the range of 2.7-4.0 pod weight/plant, compared to $2.7 \mathrm{pod}$ 
weight/plant in the control plants (Abd-El-Khair et al., 2010). On other study has reported that chemical inducer of $\mathrm{KH}_{2} \mathrm{PO}_{4}$ with seed treated increase the weight of pods/plant $75.7 \mathrm{~g}$, as compared with control $50.7 \mathrm{~g}$ (El-Hendawy et al., 2010).

The highest number of seeds/plant was recorded on ILB 938 variety inoculated with and Pf 10 (44.12) and Pf 9 (17.32). On other study, (El-Hendawy et al., 2010) had reported that chemical inducer of $\mathrm{KH}_{2} \mathrm{PO}_{4}$ with seed treated increase the number of seeds/plant 58.3, when compared with control 42.8 .

In the present study, IAA productions in all P. fluorescens isolates were positive and also indicate their finding. Similarly, Plant growth promoting rhizobacteria (PGPR) traits showed positive for the traits of IAA (Ramyasmruthi et al., 2012). The ability of bacteria to produce IAA in culture depends on the availability of precursors. Similarly, it has been reported that IAA production by PGPR can be influenced by substrate availability (Mirza et al., 2001).

It is expected that inoculation with $P$. fluorescens isolates containing PGP characteristics consequently promote root, shoot growth and lateral roots as well as nodulation. The ability of bacteria to produce IAA in the rhizosphere depends on the availability of precursors and uptake of microbial IAA by plant. Microbial biosynthesis of IAA in the soil is enhanced by tryptophan from root exudates or decaying cells (Benizri et al., 1998) and also improves plant growth by increasing the number of root hairs and lateral roots (Okon and Kapulnik, 1986).

In this study, mostly all isolates of $P$. fluorescens were able to produce ammonia. Similarly, $P$. fluorescens isolate was produced ammonia as reported according to (Ramyasmruthi et al., 2012). Production of inhibitory volatiles may increase the survival rate of bacteria in soil, by eliminating potential competitors for nutrients (Mackie and Wheatley, 1999).

In the present study, all isolates of P.fluorescens bacteria showed zone of phosphate solubilization. Isolates 1, 3 and 9 of Pfluorescens showed the clearer zone in PVK medium. Similarly, the highest phosphate solubilization zone was also recorded by Pseudomonas sp $p$. on PVK medium (Kumar et al., 2012).

To conclude that, application of fungicides for plant disease control are largely affecting human health, normal flora of soil and environment and also pathogenic fungi became very fast resistant to them. For this reason, seed inoculation with Pseudomonas fluorescens isolates as a bioprimed seed showed as growth promoter and bio fertilizers are an acceptable alternative to chemical application. Based on present studies, Pseudomonas fluorescens isolates under investigation possess a variety of promising properties which make them better growth promoter that are capable of producing plant growth promoting substances, growth and subsequent enhancement of yield of the crop. The use of environmental sociable Pseudomonas fluorescens isolates also use for increasing soil fertility and production of faba bean crop through management of chocolates spot disease (Botrytis fabae).

\section{Acknowledgements}

Authors are greatly thankful to Addis Ababa University, Faculty of Science, School of Graduate Studies and Department of Microbial, Cellular and Molecular Biology for giving us the opportunity to grasp a profound knowledge and conducted this fruitful experiment.

\section{References}

[1] Abd-El-Khair H, Khalifa R, Kh M, Haggag KHE (2010). Effect of Trichoderma species on damping off diseases incidence, some plant enzymes activity and nutritional status of bean plants. J. Am. Sci. 6: 486-497.

[2] Alemayehu W (2009). The effect of indigenous rootnodulating bacteria on nodulation and growth of faba bean (Vicia faba) in the low-input agricultural systems of tigray highlands, Northern Ethiopia. MEJS 1: 30-43.

[3] Askeland RA, Morrison SM (1983). Cyanide production by Pseudomonas fluorescens and Pseudomonas aeruginosa. Appl. Environ. Microbiol. 45: 1802-1807.

[4] Benizri E, Courtade A, Picard C, Guckert A (1998). Role of maize root exudates in the production of auxins by Pseudomonas fluorescens M.3.1: Short communication. Soil Biol. Biochem. 30: 1481-1484.

[5] Bloemberg GV, Lugtenberg BJ (2001). Molecular basis of plant growth promotion and biocontrol by rhizobacteria. Curr. Opinion Plant Biol. 4: 343-350.

[6] Bric JM, Bostock RM, Silverstone SE (1991). Rapid in situ assay for indoleacetic acid production by bacteria immobilized on a nitrocellulose membrane. Appl. Environ. Microbiol. 57: $535-538$.

[7] Cappuccino JC, Sherman N (2005). Microbiology: A Laboratory Manual. Benjamin/Cummings Pub. Co., New York.

[8] Castric P (1977). Glycine metabolism of Pseudomonas aeruginosa: Hydrogen cyanide biosynthesis. J. Bacteriol. 130: 826-831.

[9] Castric PA (1975). Hydrogen cyanide, a secondary metabolite of Pseudomonas aeruginosa. Can. J. Microbiol. 21: 613-618.

[10] Chang Y, Baker R, Kleifeld O, Chet I (1986). Increased growth of plants in the response of the biological control agent Trichoderma harzianum. Plant Dis. 70: 145-148.

[11] El-Ghamry AM, El-Hai KMA, Ghoneem KM (2009). Amino and humic acids promote growth, yield and disease resistance of fababean cultivated in clayey soil. Aust. J. Basic Appl. Sci. 3: 731-739.

[12] El-Hendawy S, Shaban W, Sakagami JI (2010). Does treating faba bean seeds with chemical inducers simultaneously increase chocolate spot disease resistance and yield under yield conditions?.Turk. J. Agric. 34: 475-485.

[13] El-Mougy NS, Abdel-Kader MM (2008). Long-term activity of bio-priming seed treatment for biological control of faba bean root rot pathogens. Aust. Plant Pathol. 37: 464-471.

[14] El-Mougy NS, Abdel-Kader MM (2008). Long-term activity of bio-priming seed treatment for biological control of faba bean root rot pathogens. Aust. Plant Pathol. 37: 464-471. 
[15] Germida JJ, Siciliano SD, de Freitas JR, Seib AM (1998). Diversity of root associated bacteria associated with heldgrown canola (Brassica napus L.) and wheat (Triticum aestivum L.). Microbiol. Ecol. 26: 43-50.

[16] Glick BR (1995). The enhancement of plant growth by free living bacteria. Can. J. Microbiol. 41: 109-117.

[17] Indiragandhi P, Anandham R, Madhaiyan M, Sa TM (2008). Characterization of plant growth-promoting traits of bacteria isolated from larval guts of diamondback month Plutella xylostella Lepidoptera: Plutellidae. Curr. Microbiol. 56: 327-333.

[18] Jeffrey P, Gianinazzi S, Perotto S, Turnau K (2003).The contribution of arbuscular mycorrhizal fungi in sustainable maintenance of plant health and soil fertility. Biol. Fertil. Soil 37: 1-16.

[19] Jensen B, Knudsen IMB, Madsen M, Jensen DF (2004). Biopriming of infected carrot seed with an antagonist, Clonostachys rosea, selected for control of seed borne Alternaria spp. Phytopathol. 94: 551-560.

[20] Kiely PD, Haynes JM, Higgins CH, Franks A (2006). Exploiting new systems-based strategies to elucidate plantbacterial interactions in the rhizosphere. Microbiol. Ecol. 51: 257-266.

[21] King EO, Ward MK, Raney DE (1954). Two simple media for the demonstration of pyocyanine and fluorescein. J. Lab. Clin. Med. 44: 301-307.

[22] Kloepper JW, Leong J, Teintze M, Schrot MN (1980). Enhanced plant growth by siderophores produced by plant growth promoting rhizobacteria. Nature 268: 885-886.

[23] Kloepper JW, Schroth MN (1978). Plant growth promoting rhizobateria on radish. In: Angers, A.B. and Clarey, G., (Ed.), Proceedings of the Fourth International Conference on Plant Pathogenic Bacteria, Tennesse, New York, pp 879-882.

[24] Kumar A, Kumar A, Devi S, Patil S (2012). Screening and characterization of bacteria from rhizospheric soils for different plant growth promotion (PGP) activities: an in vitro study. Recent Res. Sci. Technol. 4: 01-05.

[25] Lifshitz R, Klopper JW, Kozlowshi M, Simonson C (1987). Growth promation of Canola (rapeseed) seedling by a strain of Pseudomonas putida under gnotobiotic conditions. Can. J. Microbiol. 33: 390-395.

[26] Loper JE (1988). Role of fluorescent siderophore production in biocontrol of Pythium ultimum by a Pseudomonas fluorescens strain. Phytopathol. 78: 166-172.

[27] Loper JE, Schroth MN (1986). Influence of bacterial source of indole-3-acetic acid of root elongation of sugar beet. Phytopathol.76: 386-389.

[28] Lorck H (1948). Production of hydrocyanic acid by bacteria. Physiol. Plant 1: 142-146.

[29] Mackie AE, Wheatley RE (1999). Effects of the incidence of volatile organic compound interactions between soil bacterial and fungal isolates. Soil Biol. Biochem. 31: 375-385.

[30] Mahmoud YA-G, Souod SMAE, Alsokari S, Ismaeil, A-E (2011). Recent approaches for controlling brown spot disease of faba bean in Egypt. Egypt. Acad. J. biol. Sci. 3: 41- 53.

[31] Malamy JE, Benfry PN (1997). Organization and cell differentiation in lateral roots of Arabidopsis thaliana. Development 124: 33-44.
[32] Mirza MS, Ahmad W, Latif F, Haurat J (2001). Isolation, partial characterization, and the effect of plant growthpromoting bacteria (PGPB) on micro-propagated sugarcane in vitro. Plant Soil 237: 47-54.

[33] Moeinzadeh A, Sharif-Zadeh F, Ahmadzadeh M, Heidari TF (2010). Biopriming of sunflower (Helianthus annuus L.) seed with Pseudomonas fluorescens for improvement of seed invigoration and seedling growth. Aust. J. Crop Sci. 4: 564570 .

[34] Nagarajkumar M, Bhaskaran R, Velazhahan R (2004). Involvement of secondary metabolites and extracellular lytic enzymes produced by Pseudomonas fluorescens in inhibition of Rhizoctonia solani, the rice sheath blight pathogen. Microbiol. Res. 159: 73-81.

[35] Okon Y, Kapulnik Y (1986). Development and function of Azospirillum inoculated roots. Plant and Soil 90: 3-16.

[36] Raaijmakers JM, Vlami M, de Souza JT (2002). Antibiotic production by bacterial biocontrol agents. Antonie van Leeuwenhoek 81: 537-547.

[37] Ramyasmruthi S, Pallavi O, Pallavi S, Tilak K (2012). Chitinolytic and secondary metabolite producing Pseudomonas fluorescens isolated from Solanaceae rhizosphere effective against broad spectrum fungal phytopathogens. Asian J. Plant Sci. Res. 2: 16-24.

[38] Rangajaran S, Saleena LM, Vasudevan $P$, Nair S (2003). Biological suppression of rice diseases by Pseudomonas spp. under saline soil conditions. Plant Soil 251: 73-82.

[39] Rodríguez H, Fraga R (1999). Phosphate solubilizing bacteria and their role in plant growth promotion. Biotechnol. Adv. 17: 319-339.

[40] Saber WIA, El-Hai KMA, Ghoneem KM (2009). Synergistic effect of Tichoderma and Rhizobium on both biocontrol of chocolate spot disease and induction of nodulation, physiological activities and productivity of Vicia faba. Res. J. Microbiol. 4: 286-300.

[41] Salisbury FB (1994). The Role of Plant Hormones in Plant Environment Interactions. Marcel Dekker, New York.

[42] Sivan A, Chet I (1986). Biological control of Fusarium spp. in cotton, wheat and muskmelon by Trichoderma harzianum. J. Phytopathol. 116: 39-47.

[43] Spaepen S, Vanderleyden J, Remans R (2007). Indole-3-acetic acid in microbial and microorganism-plant signaling. Microbiol. Rev. 31: 425-448.

[44] Subba Rao NS (1999). Soil Microbiology (Fourth Edition of Soil Microorganisms and Plant Growth). Science Publishers, New York.

[45] Vessey JK (2003). Plant growth promoting rhizobacteria as biofertilizers. Plant Soil 255: 571-586.

[46] Villacieros M, Power B, Sanchez-Contreras M, Loret J (2003). Colonization behaviour of Pseudomonas fluorescens and Sinorhizobium meloti in the alfalfa (Medicago sativa) rhizosphere. Plant Soil 251: 47-54.

[47] Voisard C, Keel O, Haas P, Defago G (1989). Cyanide production by Pseudomonas fluorescens helps to suppress black root rot of tobacco under gnotobiotic condition. Eur. Microbiol. J. 8: 351-358. 
[48] Weller DM (1983). Colonization of wheat roots by a fluorescent Pseudomonad suppressive to take all. Phytopathol. 73: $1548-1553$.

[49] Weller DM (1985). Application of fluorescens Pseudomonas to control root diseased. In: Purker, C.S., Roura, A.D., Moore, K.J., Wang, P.T.W., Kellmorgan J.F. (Ed.), Ecology and
Management of Soil Borne Plant Pathogens. American Phytopathological Society, St. Paul, pp137-140.

[50] Xie H, Pastrnak JJ, Gilck BR (1996). Isolation and characterization of mutants of plant growth promoting rhizobacteria Pseudomonas putida, GR12-2 that over produced indole acetic acid. Curr. Microbiol. 32: 67-71. 